\title{
Upper Agri Valley (Basilicata) between Geomorphology and Ancient Settle- ments
}

\section{Francesco Tarlano}

Sapienza Università di Roma, PhD student

email: francesco.tarlano@uniroma1.it

\section{Julian Bogdani}

Alma Mater Studiorum - Università di Bologna

email: julian.bogdani@unibo.it

\section{Antonio Priore}

Freelance professional geologist

email: geol.priore@tiscali.it

\section{Abstract}

In this paper we present the geoarchaeological and landscape project on the Upper Agri Valley (Basilicata). Between 2012 and 2015 we coordinated multidisciplinary research with the purpose of reconstructing the history and evolution of the territory, analysing the relationships between man and landscape from the Prehistory to the Middle Age. The studied area, an inland mountain valley situated in the ancient Lucania, is very important, because it is a fundamental route between the two coasts of Magna Graecia and because during the Roman period this valley was the territory in which Grumentum was born, one of the most important towns of Roman Southern Italy. Thanks to the dialogue between different competences, this project aims at understanding the settlements dynamics and the mutual influences between man and environment: indeed, we conducted geophysics and geoarchaeological investigations, archaeological surveys, cartographic and aerial photos studies, written sources analysis: in this way, different data are used to understand the landscape from a global point of view.

Keywords: Agri, Grumentum, Topography, Lucania, Geoarchaeology

\section{Introduction}

The Upper Agri Valley is placed in the mountain area of an inland Lucania valley that cuts the region from west to east, up to the river that flows into the Ionian Sea. For this reason, the valley floor has been an essential route between the two coasts (Tyrrenian and lonian coast) since the ancient times. This area is archaeologically known primarily for the existence of the important Roman town of Grumentum. It settlements in the countryside are less well known because archaeological investigations have mainly been focused on urbanistic questions.

Indeed, the area has been studied since the second half of the 1960s, especially for questions concerning the city of Grumentum. The landscape, instead, has never been studied, except when the Soprintendenza has to make inspections during building constructions. Therefore, in this context, we have created a research project with the Ancient Topography teaching post of University of Bologna (directed by P. L. Dall'Aglio and E. Giorgi), in cooperation with Sapienza University of Rome. This project purposes to reconstruct the ancient settlements order as well as the landscape morphology and evolution during the centuries. 
Since 2012, we directed on the field a series of multidisciplinary studies, with archaeological surveys in the districts of Grumento Nova and Viggiano and geoarchaeological research (geophysics, pollen analysis, etc.) aimed to understand the geomorphological units preferential for ancient settlements and to reconstruct the paleoenvironmental aspects. The interaction and the dialogue between competences usually operating in different fields allows the proposition of a global interpretation of the historic understanding of a landscape, as a result of natural events and human actions, and mutual relations between the two causes. In this paper, we want to introduce the research methodologies used during our project of territorial archaeology and the first results of these investigations. (F.T.)

\section{Geological and Geomorphological Research: The Geoarchaeological Investi- gations}

The Agri valley is an intermountain basin of the Southern Apennines, full-formed by tectonics in the Quaternary period, bounded by border or direct faults with Apenninic direction, filled by alluvial sediments, and defined by reliefs made of geological formations of limestone belonging to Carbonate Platform Units over the Lagonegro Units made by basinal silico-calcareous marl. The tectonics created the conditions for the valley's disposition; the plio-pleisticenic lake basin gradually dried up due to the opening of a dam threshold for natural tectonic causes (Priore, 2010: 11-19).

The valley is quite flat, but its uniformity is interrupted by alluvial fans and stream terraces (that testify to the alluvial activity of the area) and by predominantly limestone hills. The alluvial fans are easily distinguishable on the base of the southern slopes of the Volturino - Monte di Viggiano mountain chain. The east area of Upper Agri Valley, close to Lake Pertusillo, is flat but terraced with high borders. On the west side, northwest from the hill of Monticello, Tramutola, the river engraving is less clear with the terraces' bor- ders lower and closer to the river (Tarlano, 2013: 233-40). For what concerns the river flow, we can underline a migration of the river bed from north east to south west, produced by the sediments of the alluvial fans from the southern slopes of the Volturino chain.

Thanks to the analysis of the valley, we can note a constant evolution of meandering, much more evident in the area upstream and west of Grumentum. In the east area, however, the river has an anastomosed path near the Lake Pertusillo and, going to the east, the river flows deeply embanked. The different morphological nature of the river bed is conditioned by the territory, and by lithologies and tectonics, that influence the whole region.

We studied the geomorphology of the valley, starting with a field survey and then we arranged some investigations with the purpose of identifying the underground structures related to other depositional events. For instance, we found some paleo channels of the river Agri, that testify to the evolution and migration of the river bed. We used Electrical Resistivity Tomography (ERT), very useful for the identification of natural or anthropic interred structures.

Near the ERT stringings, we dug with an excavator some sample tests, useful to propose a stratigraphic analysis of the first metres underground. The stratigraphy allowed to us to identify the last depositional events in the area, considering the distribution and the depth of the layers. During the excavation, we also collected some samples for pollen analysis and for radiocarbon dating, for a vegetational and paleoenvironmental interpretation of the data.

Moreover, we studied the aerial photos from different periods: in fact, we noted a lot of differences in the landscape between the first flight (1951) and the current flights, especially in terms of the river Agri flow, the woods' coverages and the alluvial shapes.

In the geomorphological survey, the preliminary activity of aerial photos analysis is fundamental to point out the shapes of a landscape in the third dimension. The study of 1951 aerial photos 


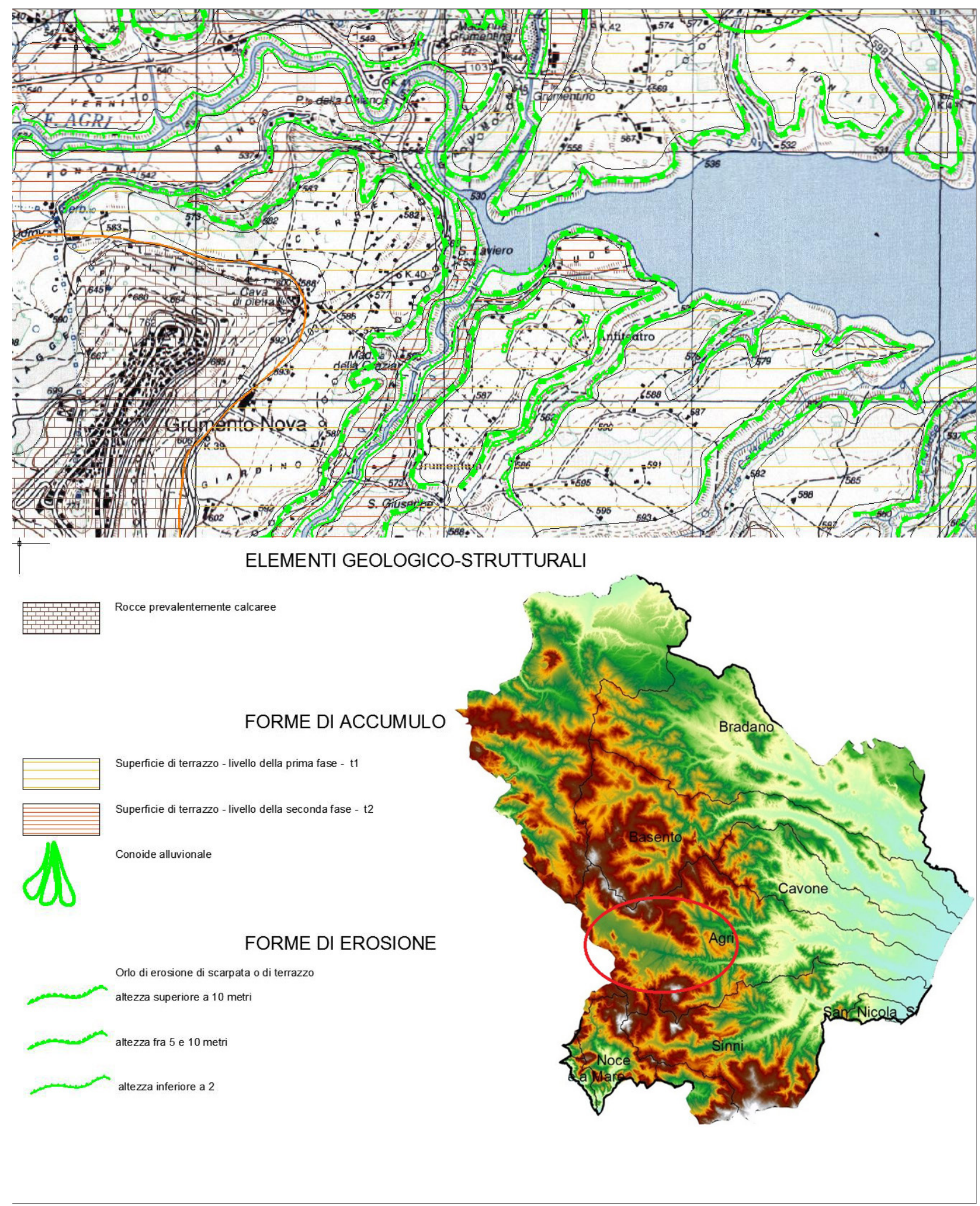

Fig. 1. Excerpt from the Geomorphological Map of the Upper Agri Valley (top); physical geography of Basilicata and localisation of the studied area (bottom). 


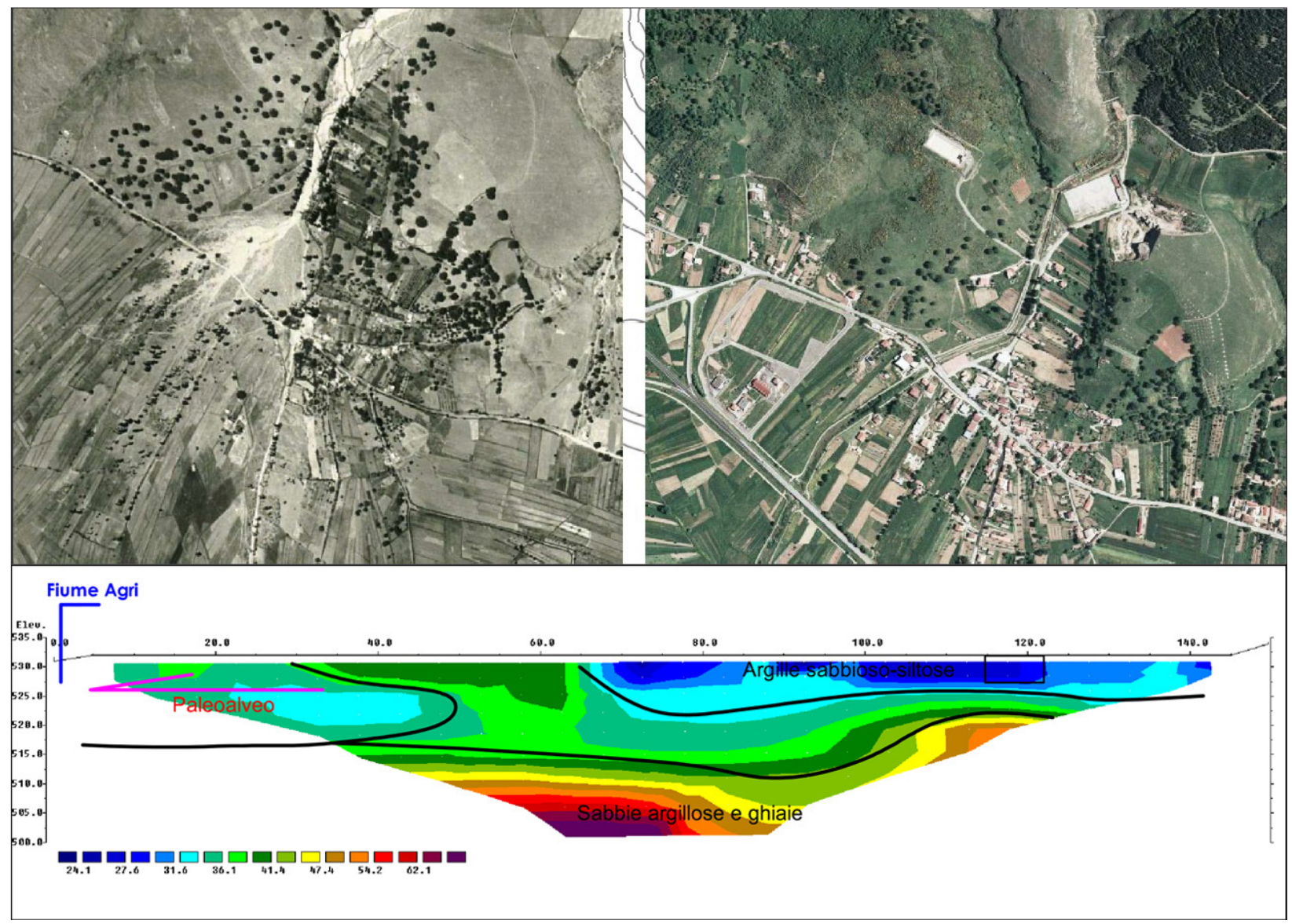

Fig. 2. Evolution of a landscape. (top): excerpts from the aerial photos (1951 and 2003); (bottom): a Geo-electrical section with the Agri river and some paleo-channels.

with the stereoscope, and their overlap with the current photos, allowed us to understand how the river bed changed its path. So, we found that the alluvial fans are still dynamic, and that they carried out sediments in the Agri basin quickly and violently, before the building of the river bank and other hydraulic control structures. The wood coverage also was different in 1951, less wide than now. In the end, the aerial photos helped us in the identification of anthropic interred structures, thanks to the stereoscopic vision.

ERT exploits the features of the material to be crossed from the electricity, so any resistivity anomaly is linked to interred objects. The data processing, together with a geological research, allows us to find interesting elements of the paleo environments. In fact, thanks to the ERT, we verified the repositioning of the Agri river bed; furthermore, in some cases, the results permitted us to locate some very interesting anomalies, attributable to interred ancient buildings.

The sample excavations pointed out the surface geology and stratigraphy in which it's been possible to distinguish sedimentary and granulometric patterns and the particle disposition. The description of the stratigraphic elements allowed us to reconstruct the energy transport and depositional environments and to recognise any anthropic element. The regular samples collection on the exposed surface of the excavation has been useful to analyse pollen in layers dated by radiocarbon.

The pollen analysis is based on the extraction, identification and interpretation of pollen grains found in the samples. Basically, with the analysis of the pollen grains, we can compile a list of plant life useful for the paleo vegetation reconstruc- 
tions and for the identification of anthropogenic elements, explaining the relationship between man and environment. During our first analysis, the samples have been particularly poor of pollen, with little pollen grains and few palynomorphs. The discovery of some pollen grains of cereal was very interesting, meaning an important presence of this plant in the fields all around Grumentum.

A.P.

\section{Archaeological Investigations: The Re- search Methodology and the Data Man- agement}

The reconnaissance surveys of DISCI (History, Culture and Civilisation Department), University of Bologna (2012-2014) involved, to varying degrees, the territories of three cities: Grumento Nova, Viggiano and Spinoso. The total coverage of the Upper Agri Valley with intensive surveys wasn't the subject of the first phase, just ended, of this project. In fact, the main purpose was to investigate in detail an important part of this valley, around the ancient site of Grumentum. The sample of the territory under investigation has been extended to cover the entire width of the valley, in the northeast-southwest direction, limited by the hills of Montagna Grande di Viggiano to the northeast and the hills of Monti della Maddalena to the southwest. The presence of the archaeological site of Grumentum within the investigated area on one hand prevents us from using this sample as the basis for an efficient modeling of the settlements distribution for the entire valley, but on the other hand allows us to contextualise better the ancient settlement within the territory.

The intensity of the intervention was chosen for various reasons and provided mixed results. Because of the limited time available and the fact that all three campaigns were carried out in the same period of the year (autumn) it was decided to carry out an intensive reconnaissance on all the land surfaces characterised by excellent and good visibility; the vast majority were freshly ploughed fields (given the season of the year). Also investi- gated with good resolution were those fields with average visibility, fields that because of low or absent vegetation, allow an easy identification of mobile finds or structures on their surface, even if they weren't ploughed in depth. The areas that, for various reasons, (the most common due to the presence of fences or high and dense vegetation) do not allow the immediate identification of artefacts and structures, generally they haven't been visited. This choice reduced the investigable and investigated areas within the test area; however, it also has ensured good reliability of the data (presence or absence of artefacts or structures) for the investigated areas. In any case, for each topographical unit the presence or absence of archaeological indicators has been reported. The absence of the archaeological settlement, in fact, isn't itself a safe and sufficient indication, for the exclusion of the archaeological potential. There are frequent cases of topographic units that have not given sufficient archaeological material to justify the presence of such a site, but the fact may be due (and in most cases is due) to the poor visibility. On account of this fact, these areas are still pointed to for particular attention in any future research, because with more favorable visibility conditions, or changed use of land, they present a higher archaeological potential.

Systematic reconnaissance were complemented by targeted surveys to areas or sites superficially known from earlier bibliography and that were therefore necessary to document in a more appropriate and comprehensive way. Also performed were punctual surveys in locations identified by local people, an instrument found very useful.

All the archaeological areas have been documented in a uniform way and according to updated standards. This is a very important achievement when considering that the area that was the subject of the search, although object of excavations and accurate researches, has never been investigated in its entirety. Each site or area interested by archaeological finds was properly located using GPS equipment, in order to register, in the most appropriate way, possible extension and areas of 


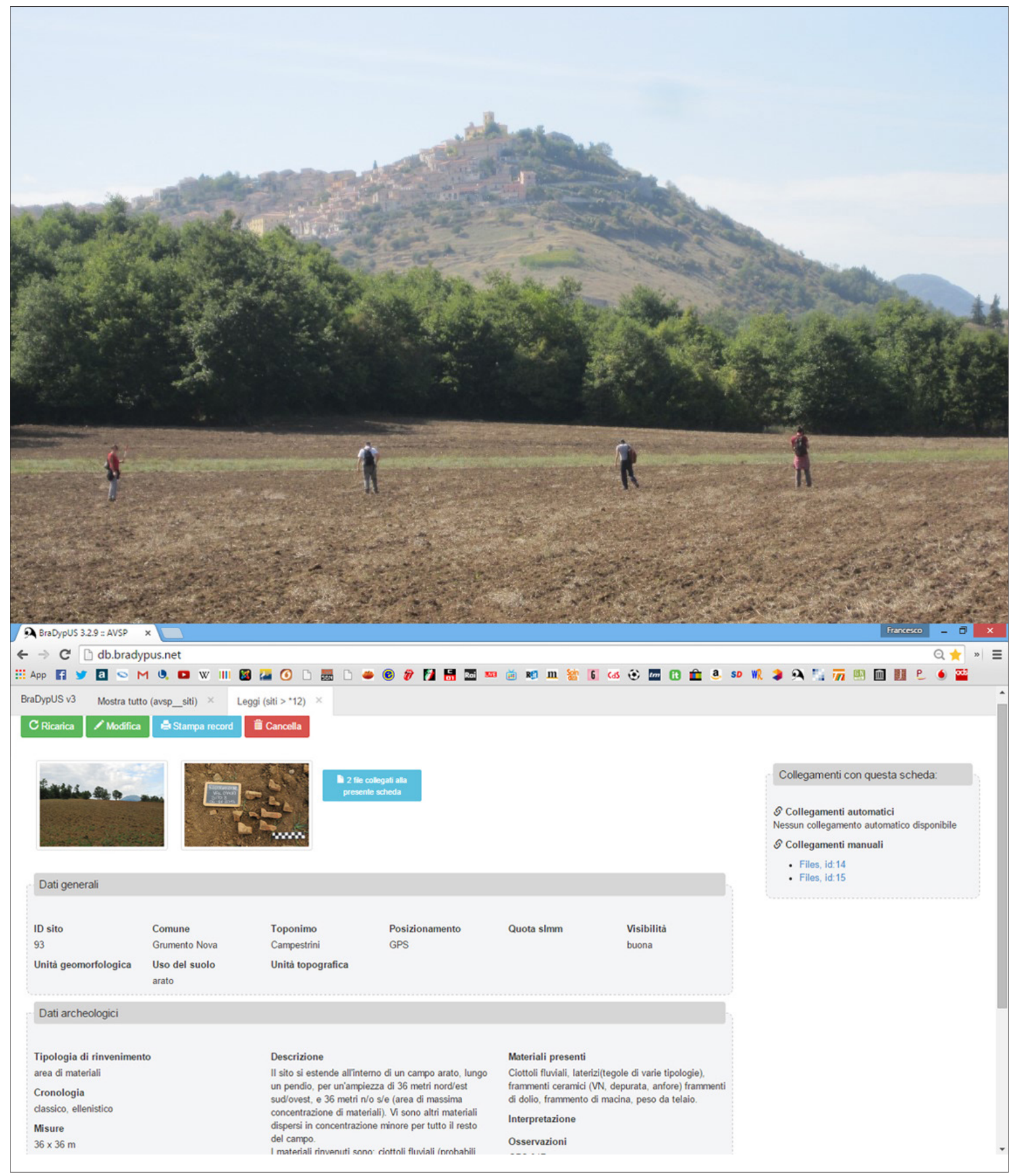

Fig. 3. Agri Valley Survey Project. (top): archaeologists during the Upper Agri Valley survey; below: the archaeological database. 
the greatest concentration of finds and/or structures. It was not possible to carry out the collection of archaeological material identified because of the agreements and requirements of the Archaeological Superintendence (the peripheral body of the ministry that deals with the management and enhancement of the archaeological heritage) prevented categorically any abnormal alteration of deposits of archaeological interest, even those just on the surface. The reconnaissance groups, however, were supported by experts of archaeological material that provided a quick identification of the main ceramics classes in each sites, and where and if it was necessary to create a graphic documentation of detail of the most significant forms and types. In exceptional cases and only where the inaction would have put at risk the preservation of materials furniture, we proceeded to the collection of artefacts, which after a preliminary filing were delivered to the Superintendence. Each area has been also adequately documented with photographs and at the end the data sheets on the field were compiled. All this material has been organised into a geographic information system (GIS), specially structured, which also collects the basic topographic and geologic maps, as well as processing and spatial analysis on the data collected. The GIS is complemented by a relational database, fully managed via the web, which contains all the data sheets and an important selection of the photographic material. For the table data base management in this project, we used the BraDypUS open source relation system (MIT licence, http:// bradypus.net), already used in archaeology by several national and international projects. The online database provides access, accordingly at different levels, to all members of the mission and also allows the sharing, in real time, of information with the agencies responsible for the protection and enhancement of archaeological heritage, mainly the Superintendence of Basilicata. As already experienced in other projects, this database could be the starting point in the future, the main core of an online publication of all the information at our disposal, publication that requires special attention, in order to ensure the safety and integrity of the deposits, and for this reason should be done in close collaboration with the Superintendence.

The entire platform (GIS and database) has been conceived to be modular and extendable in the future, in the desirable case that this first project will be extended horizontally, to other cities of the area, and vertically, with higher resolution of investigations in some areas of particular interest, or the visit and investigation in other periods of the year in areas that were conditioned by lack of visibility or accessibility in the countryside.

J.B.

\section{Historical and Topographical Inter- pretation of the Collected Data: Ancient Settlements in Upper Agri Valley}

The Upper Agri Valley has archaeological data from the Ancient Neolithic (Bianco, Preite \& Natali, 2010: 21-38; Pellegrino, 2010: 39-44) but the territory starts to be densely settled during the Bronze Age: especially during the Middle Bronze Age, with the Apenninic Culture, we recorded the development of many settlements on the hill tops, usually seasonal, and linked to other settlements on the valley floor, placed beside transhumance routes. Beyond the known sites of Civita di Paterno and Murgia Sant'Angelo di Moliterno (Bianco, 1997: 41-61) we discovered new sites on the hills, defined by scattered pottery that can be attributed to the Apenninic facies.

Some of these sites were surely used during the First Iron Age too. However, the scarcity of archaeological data attributed to the Archaic period, already registered by the previous studies and investigations, continues after our survey project, and must be caused by the absence of data, and not by the absence of sites, evidently still undiscovered. Indeed, around this period, we have only some disarranged graves discovered in the countryside of Marsico Nuovo and dug in the last century (Bottini, 1997: 65-74). The Upper Agri Valley was probably controlled by the Oenotrian ethnos, who occupied the inland Agri and Sinni valleys and who differentiated from the Choni be- 


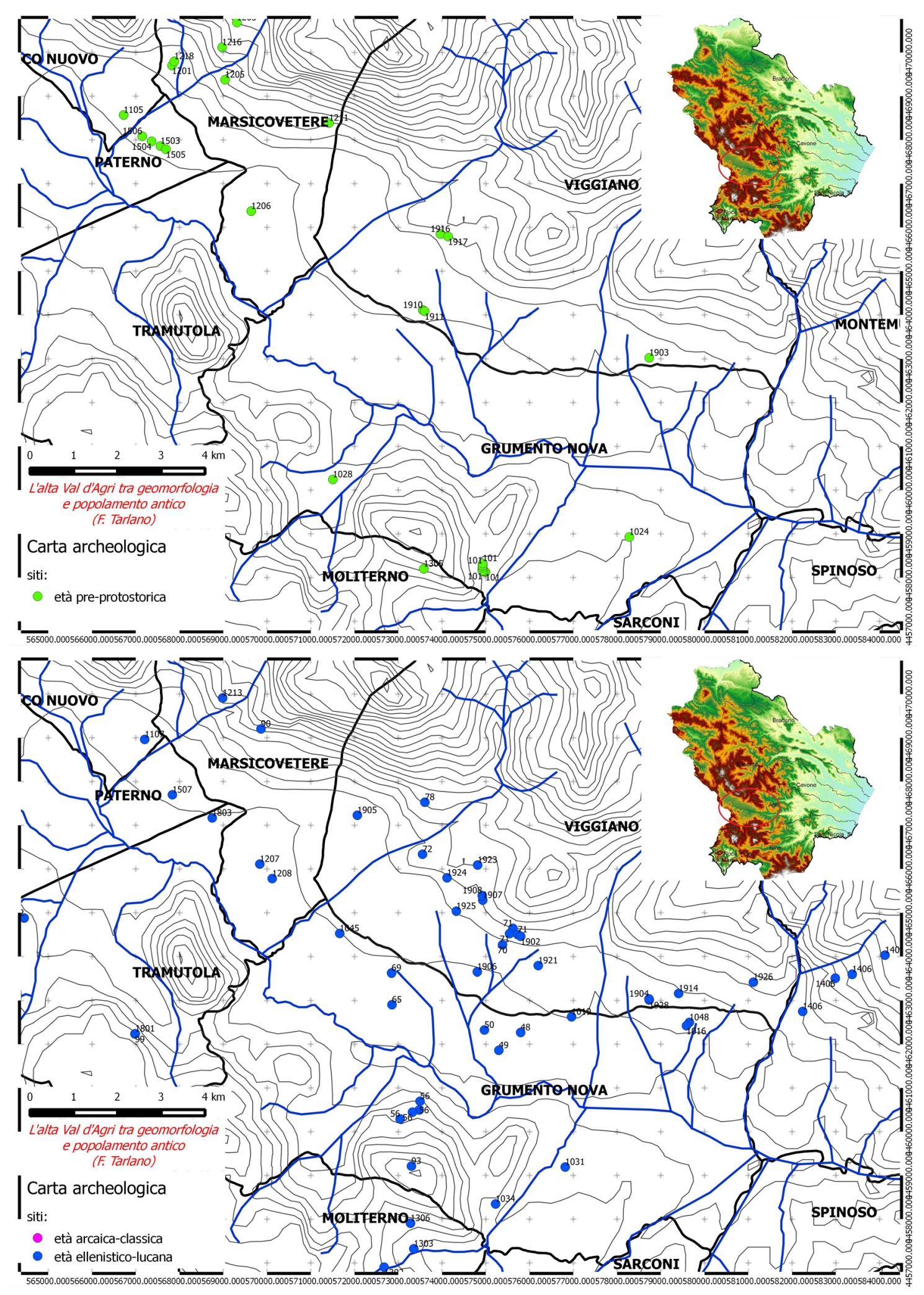

Fig. 4. GIS Archaeological map of Upper Agri Valley. Above: the pre-protohistoric sites; below: the Archaic, Classic, Hellenistic and Lucanian sites. 
cause of the Tyrrenian influences, especially in the burial tradition, with a supine position instead of a crouched position in the graves (Bianco \& Tarlano, 2011).

The situation radically changes starting mid fifth century BC, when we imagine the "Lucanisation" of the whole region.

In this context we have a lot of archaeological discoveries, datable to the Ellenistic-Lucanian period, when local Hellenised people settled some hilltop fortified sites, suitable for the control of the district. This settlement system is completed by a thick net of small farms, buildings and sanctuaries, placed on the valley floor and especially close to the slopes and on the foothill area: these sites, in some cases, continue to be settled in the Roman Republican period too. Beyond the sites already known, like the cemeteries in Gracalicchio (Bottini, 1997: 81-114), Valloni, Catacombelle, Guardemmauro and Pagliarone, and the farms in Serrone, Masseria Nigro, San Giovanni, Fosso Piano dei Valloni, Matinelle, Piani Parete, and Valdemanna (Russo, 2006: 19-57) we discovered some new scattered artefacts areas, that can generally be interpreted as farms, or small residential areas, in the districts of Grumento Nova (Campestrini), Spinoso (Piana Difesa, Ferriere, Tempagnata), Marsicovetere (San Giovanni), and Viggiano (La Monaca, Mulino Spolidoro, Valloni). The fortified sites on the hilltop already known are Madonna del Vetere and Castelli (De Gennaro, 2005: 40, 53$54)$ and we added some new sites with the same typology (such as walls built with polygonal stone bricks) discovered in II Monte - Santo Spirito and likely settled since the First Iron Age.

The first relationships between the Romans and the Lucanian are dated from the end of the fourth century BC. In this period, the Lucanian, joining Greek urban patterns, founded the most important village in the valley, Grumentum. Differently from the hilltop sites, the town is localised on a bottom valley terrace and has an orthogonal road grid. This typical Greek pattern is also influenced by the first contacts with Rome. Since the city is positioned in an inland area, the Romanisation here was a very slow process, ended only after the Social war, during the I century BC, when Grumentum became a Roman colony (Tarlano, 2014: 285-98). Later, the town remained a focal point for whole region, during the Imperial Age until Late Antiquity. Therefore, quite common Lucanian sites endure during the Roman Republican period.

Certainly, the district of Grumentum, saw the viritanae assignments of parcels during the Gracchan period and this was considered an important and solid Roman presence (Tarlano, 2010: 77-90). In fact, the institution of a praefectura was indispensable to resolve any disagreement between Roman citizens (Gallo, 2011: 53-71). Some of the sites discovered by us have a first phase attributed to the second half of the second century BC Isites of Fontana - San Vito, Porcili, Capizzo).

During the Social war, the whole territory was subjected to the devastations of the conflict. Maybe in the Sillan or Cesarian period a first large group of veterans was transferred in the Upper Agri Valley, connected to the colony foundation: indeed, during the lulio-Claudian period, the centre was particularly thriving, with an intense building vitality.

The countryside too, in this period, is reoccupied and strongly exploited, through the settlement pattern of Roman villa. Beyond the known sites of Barricelle (Gargano, 2010: 67-76), Maiorano (Nava, 2003: 935-1000) and Finaide (Bottini, 1997: 22-23; Cifani, Fusco \& Munzi, 1999-2000: 439-60) we discovered, thanks to the archaeological survey, a lot of new settlements that reproduce the same typology and chronology. The Imperial villa, usually settled until the High Middle Age, is very common in inland Basilicata (See Russo \& Di Giuseppe, 2008) and is linked to agricultural and pastoral activities. Most of the new found sites are dated to the Imperial period, confirming the transformation dynamics of landscape typical of the Roman period. The Upper Agri Valley is the most fertile inland alluvial plain in the region and the sites of Boschigliuolo, Fosso dei Tufi, Valloni, Fossato, Fontana-San Vito, Porcili, Finaita and Capizzo can be interpreted as Imperial villas, with several settlement phases, from the second-first centuries $B C$ to the fourth-fifth centuries $A D$, and 


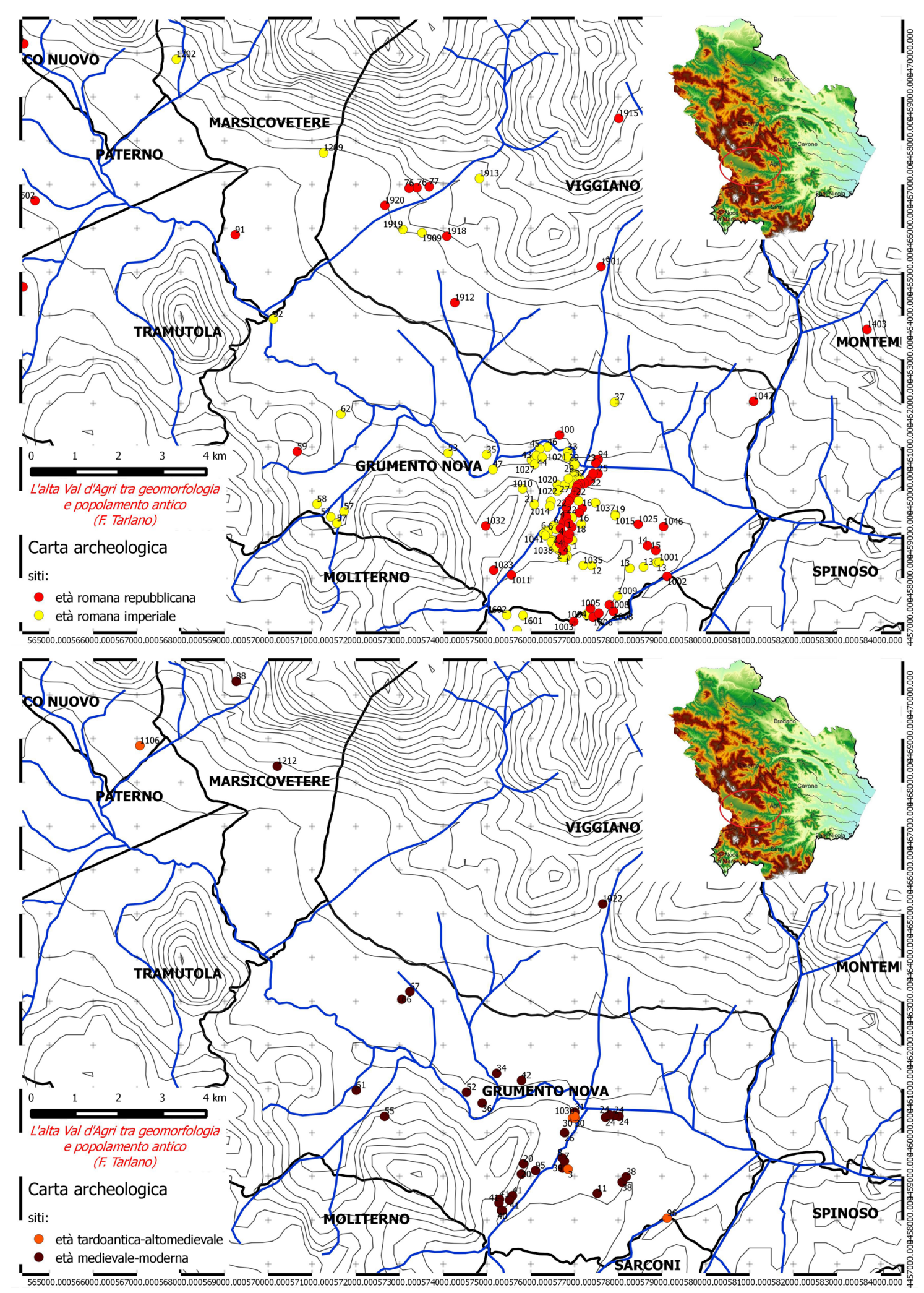

Fig. 5. GIS Archaeological map of Upper Agri Valley. Above: the Roman Republican and Imperial sites; below: the Late Antique and Medieval sites. 
in few cases until the sixth-seventh centuries $A D$ (i.e. Capizzo).

Starting from the High Middle Ages, following a common dynamic, the town loses its centrality and the slow abandonment is associated with the birth of new hilltop control centres, the Medieval villages that amount to the poleographic structure of the valley.

For what concerns the evolution of the landscape, and the relationships between geomorphological units and settlements, we can suppose the Upper Agri Valley, as a mountain inland area, in historic period was subjected to quite negligible transformations. The only alluvial plain where the surface is pretty tight, is lacking in archeological data because it is covered by alluvial modern or current layers. During the Bronze Age, in part in the Lucanian period and in the Middle Ages too, the hilltops and the peak paleosurfaces are the morphological units more settled. On the other side, in the Roman period land in part during the Lucanian period too) the alluvial terraces (of order I, II and, less, III), the alluvial fans and basically the whole foothill area, further from the river Agri, are the prevailing morphological units. The repositioning of the river bed during the historical period is localised in the alluvial plain, while the alluvial fans produced by the left tributary streams sometimes cause problems of hydrogeological instability. Generally, the valley had a hydrographic network firmer than the current network.

F.T.

\section{References}

Bianco S, 1997: L'alta Val d'Agri nell'età del bronzo, in Bottini P (ed.), Il Museo Archeologico Nazionale dell'alta Val d'Agri: 41-61. Alfagrafica Volonnino, Lavello.

Bianco S \& F Tarlano 2011: Valsinni Monte Coppolo. Le fortificazioni italiche del IV sec. a.C., Catalogo della mostra, a cura della Soprintendenza per i Beni Archeologici della Basilicata - Museo Archeologico Nazionale della Siritide, PIT Metapontino, Potenza.

Bianco S, A Preite \& E Natali 2010: Antropizzazione pre-protostorica nell'alta Val d'Agri, in Tarlano F (ed.), Il territorio grumentino e la valle dell'Agri nell'antichità: 21-38. Bradypus, Bologna.

Bottini P, 1997 (ed.): Il Museo Archeologico Nazionale dell'alta Val d’Agri, Alfagrafica Volonnino, Lavello.

Cifani G, U Fusco \& M Munzi 1999-2000: Indagini topografiche nel suburbio di Grumentum: le dinamiche insediative, Archeologia Classica, 51, 439-60.

De Gennaro R, 2005: I circuiti murari della Lucania antica (IV-III sec. a.C.), Pandemos, Paestum.

Gallo A, 2011: L'agro pubblico in Lucania, le prefetture e il Liber Coloniarum, Agri centuriati 8, 53-71.

Gargano MP, 2010: La villa romana di Marsicovetere-Barricelle (Potenza), in Tarlano F (ed.), Il territorio grumentino e la valle dell'Agri nell'antichità: 67-76. Bradypus, Bologna.

Nava ML, 2003: L'attività archeologica in Basilicata nel 2003, in Alessandro il Molosso e i "condottieri" in Magna Grecia. Atti del quarantatreesimo convegno di studi sulla Magna Grecia: 935-1000. Istituto per la Storia e l'Archeologia, Taranto.

Pellegrino A, 2010: La sepoltura neolitica in località Molinara (Marsicovetere-Potenza), in Tarlano F (ed.), Il territorio grumentino e la valle dell'Agri nell'antichità: 39-44. Bradypus, Bologna.

Priore A, 2010: Geologia e geomorfologia dell'alta Val d'Agri (Basilicata), in Tarlano F (ed.), Il territorio grumentino e la valle dell'Agri nell'antichità: 11-19. Bradypus, Bologna.

Russo A, 2006 (ed.): Con il fuso e la conocchia. La fattoria lucana di Montemurro e l'edilizia domestica nel IV sec. a.C., Finiguerra, Lavello.

Russo A \& H Di Giuseppe (ed.) 2008: Felicitas temporum. Dalla terra alle genti: la Basilicata settentrionale tra archeologia e storia, Finiguerra, Lavello. 
Tarlano F, 2010: La centuriazione nel territorio di Grumentum, in Tarlano $F$ (ed.), Il territorio grumentino e la valle dell'Agri nell'antichità: 77-90. Bradypus, Bologna.

Tarlano F, 2013: Alcune riflessioni sul rapporto tra geomorfologia e popolamento in alta Val d'Agri tra la romanizzazione e l'alto Medioevo, in Mastrocinque A (ed.), Grumento e il suo territorio nell'antichità: 23340. Archaeopress, Oxford.

Tarlano F, 2014: Le aree interne della Basilicata meridionale tra mondo lucano e romanizzazione: l'alta valle dell'Agri, in Dall'Aglio PL, Franceschelli C \& Maganzani L (ed.), Atti del IV convegno internazionale di studi veleiati: 285-98. Ante Quem, Bologna. 